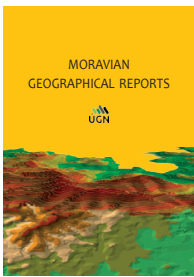

MORAVIAN GEOGRAPHICAL REPORTS

\title{
The current status of orchard meadows in Central Europe: Multi-source area estimation in Saxony (Germany) and the Czech Republic
}

\author{
Michal FOREJT ${ }^{a *}$, Ralf-Uwe SYRBE ${ }^{b}$
}

\begin{abstract}
Orchard meadows are appreciated as an integrated land use of high cultural and biological value. While such meadows are typical habitats for temperate Europe, they experienced a decline in their total area during the second half of the $20^{\text {th }}$ century, both in Western and Eastern Europe. In this contribution, we compare their current area and status in terms of semantics, law, public support in general, and the efficiency of public support in both Saxony and the Czech Republic. We estimated the area in Saxony on the basis of three public mapping projects. In the Czech Republic, where no recent mapping included orchard meadows as a specific land-use type, we carried out our own mapping. Hence, we mapped 124 randomly selected plots of $1 \mathrm{~km}^{2}$. To cross-reference results from both countries, we used the pan-EU project LUCAS (Land Use/Cover Area frame Survey). According to various different sources, the orchard meadows cover 0.09-0.55\% of Saxony and 0.010.72\% of the Czech Republic. Interestingly, the results of the three mapping projects conducted in Saxony vary from each other. Although orchard meadows are supported by financial incentives of the respective governments in both countries, the Saxon approach concentrating more on individual activities (sanitation of old trees, planting, grassland management), seems more focused than the single measure practised in the Czech Republic. One key to a greater public awareness of the orchard meadow problematic can lie in the promotion of a simple expression referring to this specific landscape feature in Czech, similar to the phrase common in the German language: 'Streuobstwiese'. Our suggestion for the Czech language is: 'lučni sad'.
\end{abstract}

Keywords: Orchard meadow; Streuobst; LUCAS; agricultural policy; Germany; Czech Republic

Article history: Received 23 December 2018, Accepted 10 November 2019, Published 31 December 2019

\section{Introduction}

Orchard meadows are a phenomenon authentic to cultural landscapes in temperate Europe, spreading from the Atlantic coast (pré-verger in French) to Central Europe (Streuobstwiese in German) (Herzog, 1998). They are characterised by fruit trees with high stems, sparsely distributed on either mowed or grazed grassland. The fruit trees are ordinarily of many types and varieties and of various ages.

Orchard meadows have high ecological value as biotopes (Horak et al., 2013; Thiem and Bastian, 2014; ZillichOlleck and Bauschmann, 1991). The fruit trees serve as a substitute habitat for birds (Kajtoch, 2017) and saproxylic beetles (Horak, 2014), while species-rich grasslands often grow underneath them (Žarnovičan et al., 2017). Due to the fact that orchard meadows generate a multitude of ecosystem services and maintain biodiversity, they are valuable elements of green infrastructure in both urban and rural areas. Orchard meadows are connected to traditional ecological knowledge (Žarnovičan, 2012), cultural ecosystem services such as recreation and education (Ohnesorge et al., 2015), and the preservation of gene banks for many local fruit tree varieties (Fischer, 2007). For regulating ecosystem services, orchard meadows provide pollination, climate regulation, flood mitigation, erosion control and water purification (Herzog, 1998). Orchard meadows both grace traditional rural landscapes (Thiem and Bastian, 2014) and can construct the green infrastructure of modern cities (Tóth and Timpe, 2017).

In contrast to the above-mentioned ecosystem service values, the decrease in the economic importance of orchard meadows is attributed to transformations in fruit supply

\footnotetext{
${ }^{a}$ Faculty of Environmental Sciences, Czech University of Life Sciences Prague, Czech Republic (*corresponding author: M. Forejt, e-mail: michal.48@gmail.com)

${ }^{\mathrm{b}}$ Leibniz Institute of Ecological Urban and Regional Development, Dresden, Germany
} 
chains. Specifically, there is an overall move to intensively managed orchards and the separation of integrated land uses into singular ones - fruit production in one place and arable land or grassland in another (Herzog, 1998). The fruit production of orchard meadows is perceived as one of the most vulnerable and important ecosystem services in the cultural landscape of the Swabian Alb (Plieninger et al., 2013).

This form of traditional agroforestry has been recently surpassed by modern agroforestry systems (Nerlich et al., 2013). Orchard meadows are mentioned as a threatened feature of traditional landscapes (Antrop, 2005). After the expansion of fruit trees during the $18^{\text {th }}$ and $19^{\text {th }}$ centuries and the peak of orchard meadows in the middle of the $20^{\text {th }}$ century, numbers have declined throughout the second half of the $20^{\text {th }}$ century in both democratic and socialist parts of Europe (Herzog, 1998). The decline of the total orchard meadow area was reported in eastern Germany as 37\% in the period 1968-2008, which was the largest decrease among the studied types of 'trees outside forests' (other types discussed were hedgerows, isolated trees or woodlots: Plieninger et al, 2012). The decline was stronger in north-western Germany, with a $74 \%$ decrease from 1979 to 2009 (Umweltbundesamt, 2010, p. 89). A milder decrease $(22 \%)$ was recorded in south-western Germany during a similar period (Plieninger et al., 2015b), and in some locations there was even an increase during the last century (Plieninger, 2012). Radical decline of the orchard meadows area was reported from central Slovakia between 1950 and 2010 (Hanušin and Lacika, 2018). The area of non-forest woody vegetation, including fruit trees and a number of individual features, declined in the second half of the $20^{\text {th }}$ century in the hilly region of eastern Czech Republic (Demková and Lipský, 2015).

At present, orchard meadows are further threatened by agricultural intensification, urbanisation (Plieninger et al., 2015b), and the abandonment of undergrowth and tree management (Milton et al., 1997; Demková and Lipský, 2015). As described for the case of Slovakia, many orchard meadows are managed by the elderly, and thus the land maintenance in rural regions is threatened by the loss of traditional approaches and emigration of younger generations to urban regions (Špulerová et al., 2015; Žarnovičan, 2012).

Despite a certain level of public support for the managers of orchard meadows, it is not enough to guarantee a sustainable maintenance of current plots, and woefully insufficient for the establishment of new plots, as was shown in Lower Austria (Schönhart et al., 2011) and the Dresden area (Ewert, 2018). There have been measures proposed directly for improving orchard meadow policies, such as adding orchard meadows to the habitat list of Annex 1 (92/43/CEE Directive) (Kajtoch, 2017), or increasing premiums within the framework of the Agri-Environmental Policy (Schönhart et al., 2011). Some authors have suggested new management practices: for example, increasing harvest efficiency by shared mechanisation; providing an added value to the fruit by processing it (Schönhart et al., 2011); introducing the cultivation of energy crops in the understorey; and intensifying the processing of fruit into juices (Plieninger et al., 2013).

One problem with such measures is that many orchard meadow managers regard farming as a hobby, and they can be an inefficient target for agricultural subsidies since they often do not qualify for the minimum requirements of said subsidies (Ohnesorge et al., 2015). One general ambition, then, is to raise public awareness and connections to some regional identity, resulting in higher local fruit consumption and the successive creation of new orchard meadows (Rost, 2011).

To create good policy and strategies, it is necessary to know how important is the role that orchard meadows play in the landscape, beginning with how much area they cover. One estimate is that $10,500 \mathrm{~km}^{2}$ of the European Union is occupied by grazed or intercropped areas with fruit, olive, and nut trees (den Herder et al., 2017). Another estimate, based on different sources from the end of the $20^{\text {th }}$ century, comes to similar results, namely that $10,000 \mathrm{~km}^{2}$ of Europe is covered by scattered fruit trees (Herzog, 1998). Den Herder et al. (2017) estimate there are $358 \mathrm{~km}^{2}$ of grazed areas with fruit trees in Germany ( $0.1 \%$ of the total area), while Herzog (1998) states that there are 2,250-5,000 km of orchard meadows in Germany, which amounts to $0.6-1.4 \%$ of the country's total area (note the difference between the objects under review). Germany's eastern neighbour, the Czech Republic, is said to have $72 \mathrm{~km}^{2}$ of grazed orchards (0.09\%: den Herder et al., 2017) or $93 \mathrm{~km}^{2}$ of orchard meadows (0.12\%: Herzog, 1998). Rapid declines are also evident here: in the first half of the $19^{\text {th }}$ century, $0.64 \%$ of Bohemia (the historical territory: $2 / 3$ of the present-day Czech Republic) was covered by agroforestry land with fruit trees (Krčmářová and Jeleček, 2017).

Several themes emerge as relevant for this paper. To accomplish better conservation and restoration of orchard meadows and to raise the appreciation of biodiversity and ecosystem services, a common terminology is required. Secondly, comparisons beyond European borders should give insights as to how this type of an ecosystem can be protected at an international scale, where subsidies already exist and what (EU) policy can do to maintain it. Finally, knowledge is needed about the precision of geo-data for this ecosystem type, about the available data to measure them and about their validity.

Therefore, the paper first clarifies the semantics of German and Czech terms, compares them and gives suggestions on how exactly to nominate this specific type of orchards in national debates. Second, the legal status and system of agricultural subsidies in both neighbouring countries are outlined. Third, we try to increase the precision of the estimated area of orchard meadows and their spatial distribution in the Czech Republic and Saxony, one federal state of Germany. The reason for choosing only one federal state in Germany is that Saxony has specific legal conditions in nature conservation, as well as completed unique land-use and vegetation mapping projects depicting orchard meadows. A similar approach is used for the Czech Republic and allows us to make a oneto-one comparison.

Previous studies had severe insufficiencies, namely den Herder et al. (2017), which took into account only those areas with fruit trees that are grazed, and Herzog (1998), which estimated the area based on non-explicit sources, for example relying on data from the Czech State Statistical Office despite orchard meadows not being explicitly recorded there. The present study is based on the multiple geodata approach. But first, we will discuss the current linguistic and legal status of orchard meadows in Saxony and the Czech Republic, and then we will continue to scrutinise orchard meadow support measures and estimate their efficiency. 


\section{Current status}

\subsection{Semantics}

The English term 'orchard meadow' started to be used by researchers from German-speaking areas who were trying to find an equivalent for the word Streuobstwiese ${ }^{1}$ (Ohnesorge et al., 2015; Schönhart et al., 2011; Steffan-Dewenter and Leschke, 2003). Another term we can encounter in English-language-based scientific literature is a 'traditional orchard', used in studies from Poland, Slovakia or the Czech Republic (Horak, 2014; Kajtoch, 2017; Špulerová et al., 2015; Žarnovičan et al., 2017). The most precise, but much longer, translation of Streuobstwiese is 'scattered fruit tree meadow' (Thiel et al., 2012).

Concerning the Czech language, there is the common word sad, which is equivalent to the English 'orchard'. It includes both intensively and extensively managed stands of fruit trees, which may also be ploughed. Expressions referring to extensively managed orchards are extenzivni sad and vysokokmenny sad ${ }^{2}$. In comparison to the German Streuobstwiese, these Czech expressions feel very professional, and they are used mostly by experts in conservation. There are also terms dividing orchards by the secondary use of the understorey, i.e. polni sad (when intercropped), luční sad (when mowed), or pastevní sad (when grazed). In Slovak, very similar to Czech, the term sadová lúka is sometimes used (Žarnovičan, 2012) to refer to the orchard meadow concept in general.

\subsection{Legal status - conservation}

Orchard meadows are not listed as a protected habitat in Annex I of the Habitats Directive of the Council of the European Communities (Council of the European Communities, 1992), nor in Article 30 of the Federal Nature Conservation Act (BNatSchG, 2019), which is valid for Germany as a whole. Some German federal states, however, do list orchard meadows as nature conservation objects. The Saxon Nature Conservation Act (SächsNatSchG, 2018) mentions orchard meadows (Streuobstwiese) in the list of protected biotopes ( $\$ 21$ Art 1 No. 4), which means that any action that can lead to the destruction or damage of the biotope is forbidden (cf. BNatSchG, Art 30 No. 2). According to one commentary to the Saxon Nature Conservation Act (Göttlicher, 999), an orchard meadow must cover an area of $500 \mathrm{~m}^{2}$ and must grow 10 trees at a minimum to qualify as a Streuobstwiese. The Czech Nature and Landscape Conservation Act (ZOPK, 2017) generally obliges all owners of trees to care for them. There is also an instance of 'remarkable tree', which ensures stricter protection, though this is used only in exceptional cases.

\subsection{Public support}

In both the Czech Republic and Saxony, specific measures supporting orchard meadows maintenance have been implemented. The Czech measure supported by the second pillar of the Common Agricultural Policy (CAP) for organic farming is called Krajinotvorný sad ('landscaping orchard'). Conditions to get this subsidy contain: growing high- or middle-stemmed trees to a minimum density of 50 trees per hectare (with a density greater than 100 trees/ha, a different program is more suitable). The trees must grow on oncea-year mowed or grazed grassland. Furthermore, farmers have to commit to work under the specified conditions for at least five consecutive years, and the trees have to be clipped at least once in the first four years after planting (Ministry of Agriculture of the Czech Republic, 2016). Together with basic and greening payments, each farmer, who is registered as an agricultural entrepreneur by the ministry of agriculture, can get approximately EUR 365/ha/year for managing the land in this way. There were 771 field blocks thusly supported, accounting for 1,009 ha $(0.013 \%$ of the Czech Republic) in total, according to government statistics from January 2018 (Ministry of Agriculture of the Czech Republic, 2018).

Orchard meadows in Saxony are eligible for support from the program Richtlinie Natürliches Erbe ('Guidelines for Natural Heritage'). This program concerns, among other topics, the sanitation of old fruit trees and planting of new fruit trees. The first goal is supported by EUR 41 (easy conditions) or EUR 75 (hard conditions) per tree, with a minimum support for one project of EUR 500 (thus, a minimum of 7 trees per project in hard conditions). Following this, one newly planted tree is supported by EUR 68 with the same minimum sum per project (resulting in at least 8 new planted trees per project). Since 2014 when the program was established, 3,907 existing trees in 68 projects have been subsidised, an average of 58 trees per project (as of Spring, 2018). During the same period, 3,866 new trees were planted in 57 projects, an average of 68 trees per project. More than twenty (22) supported projects covered both planting and restoration, although it is unclear how much they contribute to the numbers mentioned above. Thus, we can roughly estimate that at least 100 plots in Saxony have been supported by the National Heritage program. The management of grasslands can be supported by a similar measure (Richtlinie Agrarumwelt- und Klimamaßnahmen).

Both in the Czech Republic and Saxony it is possible to request direct payment for grassland management within the first pillar of CAP. There are also other publicly- and privately-funded programs aimed at the planting of new fruit trees.

\section{Methods}

To estimate the total area of orchard meadows in Saxony and the Czech Republic, we used several existing datasets (their basic properties are shown in Tab. 1), one adjusted pan-EU data source, and researcher-mapped randomly selected plots. Other comparable data sources do not differentiate orchard meadows well enough: for example, the Corine Land Cover uses the class 2.2.2 (Fruit tree and berry plantations), which matches orchard meadows with the intensive type of plantations. Moreover, Corine Land Cover uses a minimum mapping unit of 25 ha, which is inappropriate to estimate the area of orchard meadows, with their typical small scale. Because each country has different types and the extent of data sources available, our approach differs for the different states, though it is cross-referenced with the use of the LUCAS (Land Use/Cover Area frame Survey) grid data.

\footnotetext{
${ }^{1}$ Streuen $=$ scatter, Obst $=$ fruit, Wiese $=$ meadow. Sometimes the word Streuobst is also used (Herzog, 1998; Tojnko et al., 2011), which includes intercropped orchards and such landscape elements as fruit alleys, etc.

${ }^{2}$ Direct translation to English: 'orchard with high-stemmed fruit trees'

${ }^{3}$ Direct translation to English: 'orchard meadow'
} 


\begin{tabular}{llcc}
\hline Country & Dataset & Years of origin & Min. registry unit (ha) \\
\hline Saxony & SBK2 & $1996-2002$ & 0.05 \\
Saxony & BTLNK & 2005 & 0.05 \\
Saxony & ATKIS & $2013-2016$ & 1.00 \\
Czech Republic & LPIS & 2018 & 0.50 \\
EU & LUCAS & 2015 & 0.05 \\
\hline
\end{tabular}

Tab. 1: Analysed data sets on orchard meadows

Sources: Selektive Biotopkartierung 2. Durchgang (SBK2) = Selective habitat mapping; Biotoptypen- und Landnutzungkartierung $(B T L N K)=$ Mapping of biotope types and land use; Amtliches TopographischKartographisches Informationsystem $($ ATKIS $)=$ German digital topographic information system; LPIS - Land Parcel Identification System; LUCAS = Land Use / Cover Area frame Survey

\subsection{Saxony}

There were three independent projects conducted in Saxony, which mapped orchard meadows as spatially delimited patches.

Selective biotope mapping 'SBK' (Selektive Biotopkartierung $=$ Mapping of selected biotopes; LfULG, 2002) in Saxony is thought to record all biotope types that are protected by federal and state nature conservation laws (BNatSchG, 2019; SächsNatSchG, 2018). SBK was used as bases for the administrative work of the nature conservation agency. The mapping was carried out on-site by experts, basing it on the already-existing BTLNK (see below). After completion of the first pass in 1994, a second pass 'SBK2' was carried out between 1996 and 2002. Since this second set was only partially revised by the third pass in 2006-2008, SBK2 provides the last available complete dataset. Since 2009 no revision has been carried out, so while the SBK data are very precise they are also potentially out of date. Because every biotope type was mapped and described in great detail to make a sophisticated data set, some smaller areas were described only as biotope complexes, such that an exact calculation of the real biotope area is rather difficult (Syrbe et al., 2018).

A complete aerial-covering biotope mapping 'BTLNK' (Biotoptypen- und Landnutzungkartierung = Mapping of biotope types and land use) based on colour-infrared aerial views was carried out in Saxony in the years 1992, 1993 and 2005. The recent data set is available from the Saxon Nature Conservation Agency (LfULG, 2005). The resulting digital biotope maps can be more precisely spatially analysed, but since they use remote sensing data, their precision is limited; in other words, shortcomings and confusion with other similar biotopes are an ever-present possibility.

The landscape model of the German digital topographic information system (ATKIS-Basis-DLM = Amtliches Topographisch- Kartographisches Informationsystem Basis Digitales Landschaftsmodel; SGVSG, 2016) is updated separately by each federal state in Germany. The stage of project development varies among the German states. The classification system contains 190 object types. The minimum mapping unit for this system is 1 ha and therefore coarser than SBK2 and BTLNK (Tab. 1), and updates are carried out using aerial photography and more thematic details. Since then, the topographic data have been updated using high-resolution remote sensing data (SGVSG, 2016).

Based on these three projects, which spatially differ between each other, we constructed an intersection diagram expressing the probability for orchard meadow occurrence in Saxony. We assume that the probability of identifying orchard meadows is higher the higher the number of available data sources, particularly considering that newer sources tend to be more credible than the older ones.

\subsection{Czech Republic}

There is only one data source that spatially delimits orchard meadows in the Czech Republic, the Land Parcel Identification System (hereinafter LPIS). LPIS registers the land for which the discussed agricultural subsidies are provided. We took the field blocks with land use registered as 'landscaping orchard' as patches with a certain occurrence of orchard meadows. The minimum area of one field block is set to 0.5 ha.

Because these field blocks with 'landscaping orchard' land use refer only to orchard meadows registered for their organic management and receiving subsidies, we further estimated their area on the basis of our own mapping in randomly sampled squares of $1 \mathrm{~km}^{2}$. We performed the whole analysis in ArcGIS 10.5.1 (ESRI). To assure that the squares would be equally spread across the country, we used the Create Fishnet tool to create squares of $25 \mathrm{~km}$ per side (an area of $625 \mathrm{~km}^{2}$ ). Polygons smaller than $625 \mathrm{~km}^{2}$ were created around the country border. In each polygon larger than $300 \mathrm{~km}^{2}$ (i.e. approximately half of $625 \mathrm{~km}^{2}$ ) we placed one sampling square. We used the Random points tool to randomly place points and the Graphic Buffer tool to build squares around the points. Using this procedure, we prepared 124 squares of $1 \mathrm{~km}^{2}$ to be mapped. The sampling method was arbitrarily set up to give a coarse overview of the spatial distribution of orchard meadows throughout the Czech Republic.

We mapped the orchard meadows in the delimited squares on the basis of orthophoto maps provided as a web map service by the Czech Office for Surveying, Mapping and Cadastre (2016, 2017). We further used the Basic map of the Czech Republic to check for gardens and orchards for identifying patches with present fruit trees. We also used the tool Panorama at mapy.cz (the Czech equivalent to Google StreetView) to check the height of the trees and their undergrowth. Single field visits in three squares showed us that this approach is suitable (see photos on Fig. 1). The method used is comparable to one of the BTLNK and ATKIS sources which did not do on-site mapping, though we used additional sources to remote sensing. The definition used to identify orchard meadows comes from the Saxon Nature Conservation Act. We considered orchard meadows only of at least $500 \mathrm{~m}^{2}$ in area size and with 10 or more highstemmed trees scattered (approximately 20-200 trees/ha) across grassland undergrowth. A certain level of successive overgrowth was accepted. 

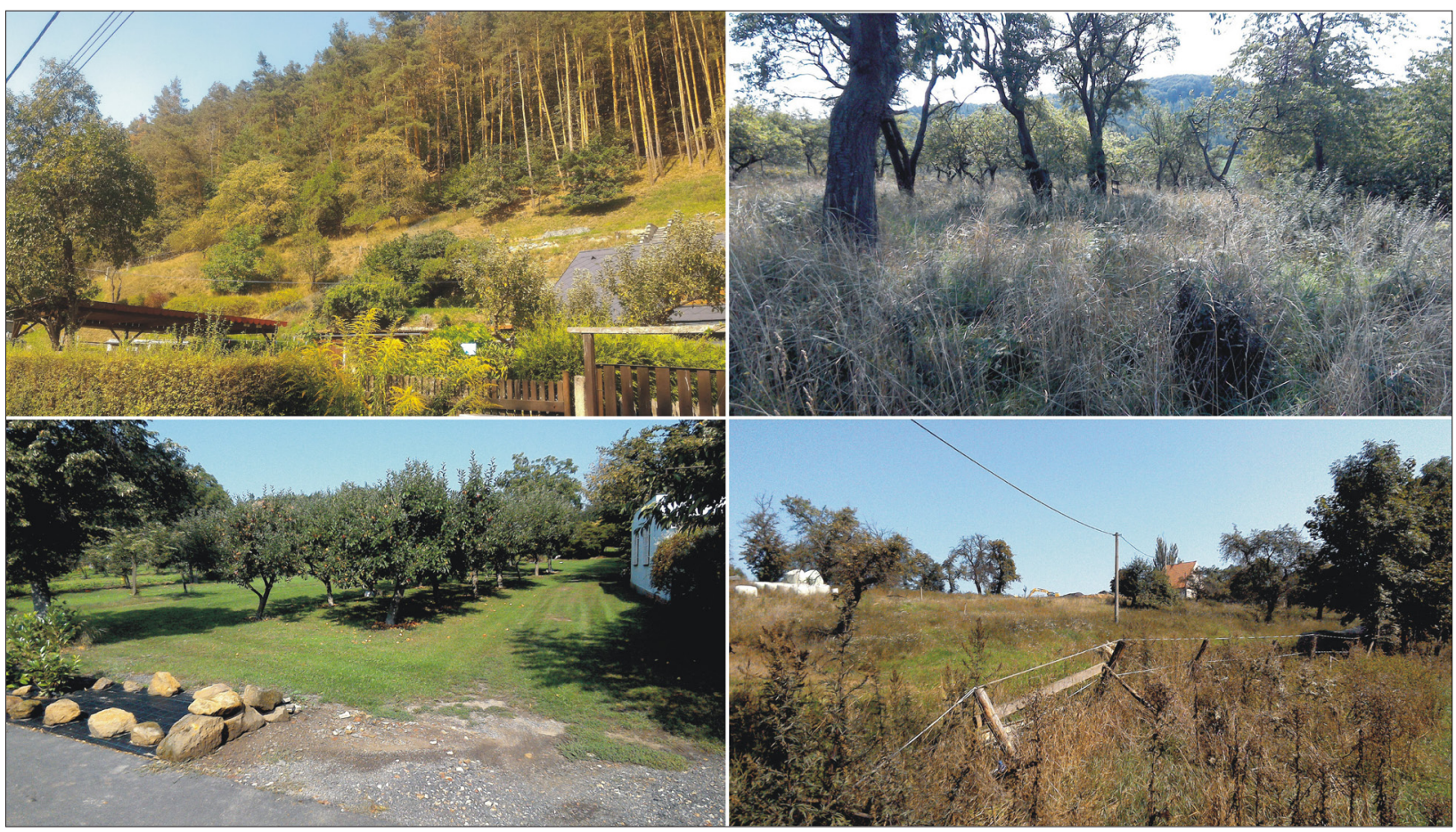

Fig. 1: The appearance of visited orchard meadows in northern Czech Republic: Moderately managed orchard meadow situated between home gardens and a forest in the recreational settlement of Bukovec (top left); Overgrown orchard meadow situated not far from the village Krušovice near Rakounik (top right); Intensively managed orchard meadow near the centre of Zichovec village (bottom left); Orchard meadow with old apple trees threatened by the construction of a bypass route, Krušovice village (bottom right). Photos: M. Forejt

\subsection{Central European context}

We further used the LUCAS grid database to compare and cross-reference the results obtained from the defined datasets from Saxony and the Czech Republic. The LUCAS database, purchased in 2015, is comprised of 273,153 fieldsurveyed and 66,604 photo-interpreted geo-referenced points (Eurostat, 2015). For each surveyed or photo-interpreted point, land use, land cover, and other data were recorded. It covers only the 28 member states of the $\mathrm{EU}$, thus Switzerland and Lichtenstein, both of which are normally considered Central European countries, were not included. Previously, the database was used to estimate the extent of wood pastures (Plieninger et al., 2015a) and other various types of agroforestry (den Herder et al., 2017).

Both studies, when considering land with fruit trees, took into the account only land with grazing management, although orchard meadows (no matter if grazed or not) are generally considered a type of agroforestry (Nerlich et al., 2013). Here, we only selected points with fruit trees as primary land cover [LC1 (primary land cover) = B71-B75 (apple trees, pear trees, cherry trees, nuts trees and other fruit trees and berries)], and we further used orthophoto and LUCAS PhotoViewer to adjust photos from each site and to verify each point for fruit tree density, stem height, and grassland undergrowth.

We applied the same definition of orchard meadows as before, including the minimum area $\left(500 \mathrm{~m}^{2}\right)$ and minimum number of trees (10). We performed this procedure for all Central European countries that are EU member states (Germany, Austria, Poland, Czech Republic, Slovakia, and Hungary). The share in area of one geographic unit was estimated by dividing the number of points matching the criteria by the number of all points for each state in the Central Europe region (den Herder et al., 2017).

\section{Results}

Table 2 presents geographical coverage of orchard meadows in the Czech Republic, Saxony, and other parts of Central Europe. Regarding to the LUCAS database, not all the fruit trees points are registered, but only those have been manually selected that doubtless represent orchard meadows with high-stem scattered trees. Relatively low values (compared to marginal distributions of orchard meadows and total acreage) are found in Hungary and Poland, while the relatively highest values are those from the Czech Republic and Slovakia. Detailed findings are presented in subsequent sections.

\subsection{Saxony}

According to the individual mapping projects, there are $44.1 \mathrm{~km}^{2}(0.24 \%$ of Saxony's total area; SBK2), 61.5 $\mathrm{km}^{2}\left(0.33 \%\right.$; BTLNK), or $15.8 \mathrm{~km}^{2}(0.09 \%$; ATKIS) of orchard meadows in Saxony (see Fig. 2). The minimum overlap between all projects is $6.1 \mathrm{~km}^{2}$ ( $0.03 \%$ of Saxony). Areas where at least two of these mapping projects agree on the occurrence of orchard meadows amounts to $26 \mathrm{~km}^{2}$ ( $0.14 \%$ of Saxony), while areas where at least one project shows the occurrence of an orchard meadow is $86.3 \mathrm{~km}^{2}$ (the potential maximum area of orchard meadows without considering different mapping criteria; $0.47 \%$ of Saxony). The interpreted LUCAS database suggests even more, namely that $0.54 \%$ of all points in Saxony are orchard meadows. The mean patch size of one orchard meadow is highest according to ATKIS (1.8 ha), and more than three times smaller according to both BTLNK (0.54 ha) and SBK2 (0.46 ha).

Orchard meadows are concentrated in central Saxony (the districts of Leipzig, Mittelsachsen, Meißen, Sächsische Schweiz-Osterzgebirge, and Dresden) in a wide strip 


\begin{tabular}{llrc}
\hline Geographic unit & Dataset & $\mathbf{k m}^{2}$ & $\%$ \\
\hline Saxony & SBK2 & 44.1 & 0.24 \\
& BTLNK & 61.5 & 0.33 \\
& ATKIS & 15.8 & 0.09 \\
& SBK2+BTLNK+ATKIS & $6.1-86.3$ & $0.03-0.47$ \\
& LUCAS & 99.7 & 0.54 \\
Czech Republic & LPIS & 10.1 & 0.01 \\
& Random squares & 437.0 & 0.55 \\
& LUCAS & 566.0 & 0.72 \\
Austria & LUCAS & 360.6 & 0.43 \\
Germany & & 1924.1 & 0.54 \\
Hungary & & 180.0 & 0.19 \\
Poland & & 623.2 & 0.20 \\
Slovakia & & 356.0 & 0.73 \\
Central Europe & & 4009.9 & 0.41 \\
\hline
\end{tabular}

Tab. 2: Orchard meadow areas in Central Europe according to multiple sources.

Sources: Ministry of Agriculture of the Czech Republic (2018), Eurostat (2015), BKG (2016), LfULG (2002), and LfULG (2005); authors' survey

starting south of Dresden, spreading northwest to the town of Meißen and west between the cities of Leipzig and Chemnitz. Concerning landscape units, orchard meadows are concentrated in Mittelsächsisches Lösshügelland ('Central Saxon loess landscape') and Östliches Erzgebirgsvorland ('Eastern Ore Mountains foothills') (Mannsfeld and Syrbe, 2008). There is a significant difference between the spatial coverage of orchard meadows in the three mapping projects. In the southwestern part of Saxony, there is a relatively high share of mapped orchard

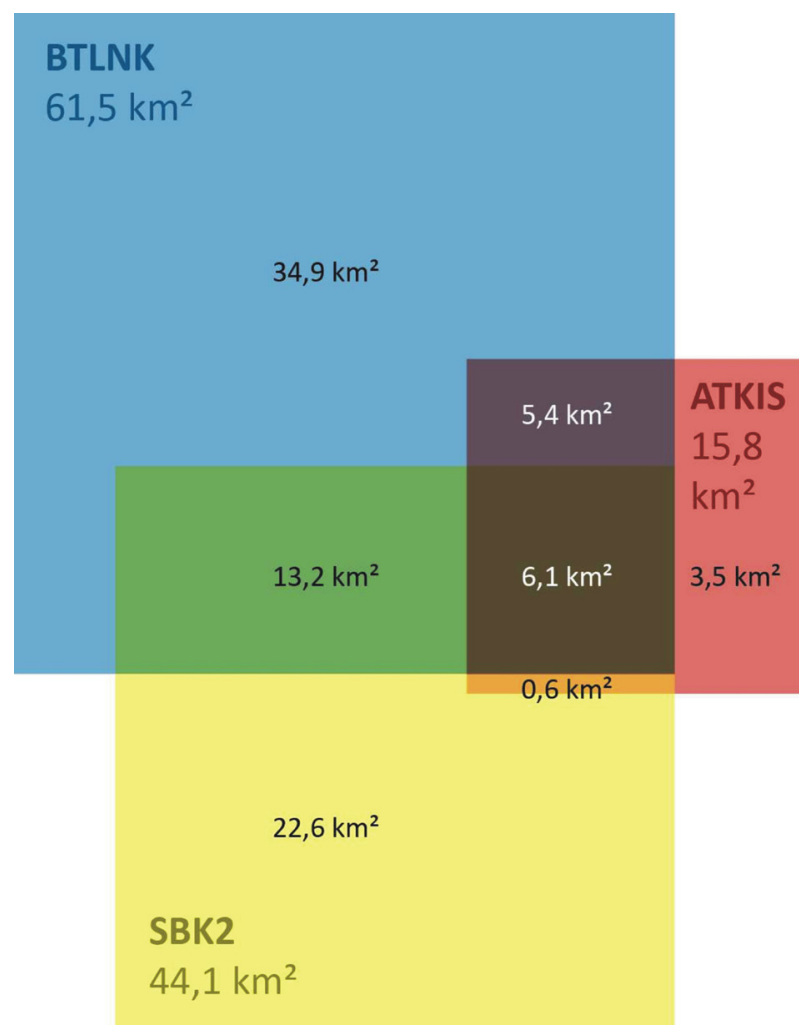

Fig. 2: Concordance in mapped orchard meadows in mapping projects in Saxony. Sources: BKG (2016), LfULG (2002), and LfULG (2005); authors' elaboration meadows in the BTLNK dataset, while SBK2 reports large areas of mapped orchard meadows in the east and in the Meißen district (see Fig. 3).

\subsection{Czech Republic}

The LPIS system for registering land that receives agricultural subsidies, records 1,009 ha of orchard meadows ( $0.013 \%$ of the Czech Republic total area) in 771 field blocks in the Republic. They are mostly present in south-eastern, eastern and northern areas of the Czech Republic, where registered orchard meadows may reach up to $0.05 \%$ of the respective region's total area (see Fig. 4A). Concerning landscapes rather than administrative units, orchard meadow hot spots seem to occur in the Bílé Karpaty ('White Carpathians'), Ždánický les ('Zdanice Forest), Ceský ráj ('Bohemian Paradise'), and České středohoří ('Central Bohemian uplands') landscapes.

According to our digital mapping (Fig. 4B), 46 of the 124 mapped squares contained at least one patch of orchard meadow. Altogether we identified 68.7 ha of orchard meadows. The maximum orchard meadow share in one square was $12.8 \%$ (near the town of Kyjov), and the minimum share was $0 \%$, which was true for 78 squares. 12 squares contained at least $1 \%$ of orchard meadows. Taking all the mapped squares together, we can calculate the average occurrence of orchard meadows in the Czech Republic as a $0.55 \%$ share of the country's total area. Again, there are apparent orchard meadows hot spots, especially eastern and partly in northern Czech Republic, and the south-western half of the Czech Republic does not show a high concentration of orchard meadows. One square, near the town of Rakovník, is a notable exception to this rule. Using the LUCAS database, we can estimate that $0.72 \%$ of the Czech Republic is occupied by orchard meadows.

\subsection{Central Europe}

In the context of Central Europe, the LUCAS database reveals that orchard meadows have the highest shares of land use in Slovakia (0.73\%) and the Czech Republic (0.72\%). The lowest shares, meanwhile, occur in Hungary $(0.19 \%)$ and Poland ( $0.2 \%)$. Orchard meadows in Germany and Austria have 
average values ( $0.54 \%$ and $0.43 \%$, respectively), which is due to very large areas with a very low density of points identified as orchard meadows (the Alps and North-German lowland).

Concerning the spatial distribution in Central Europe specifically (see Fig. 5), high concentrations of orchard meadows are found, not surprisingly, in Baden Württemberg, northern Bavaria, the Rhineland, eastern Saxony (all in Germany), in Steyerland (Austria), and the western
Carpathians (western Slovakia, southern Poland, eastern Czech Republic), mostly between $100 \mathrm{~m}$ and $500 \mathrm{~m}$ above sea level (maximum at 1,135 $\mathrm{m}$ in the Alps in Austria).

Only very rare occurrences are found north of $52^{\circ}$ latitude or in the whole of Hungary. Concerning our focal countries, low densities of orchard meadows are recorded in southwestern Saxony and north-western and north-eastern Czech Republic (Fig. 5)

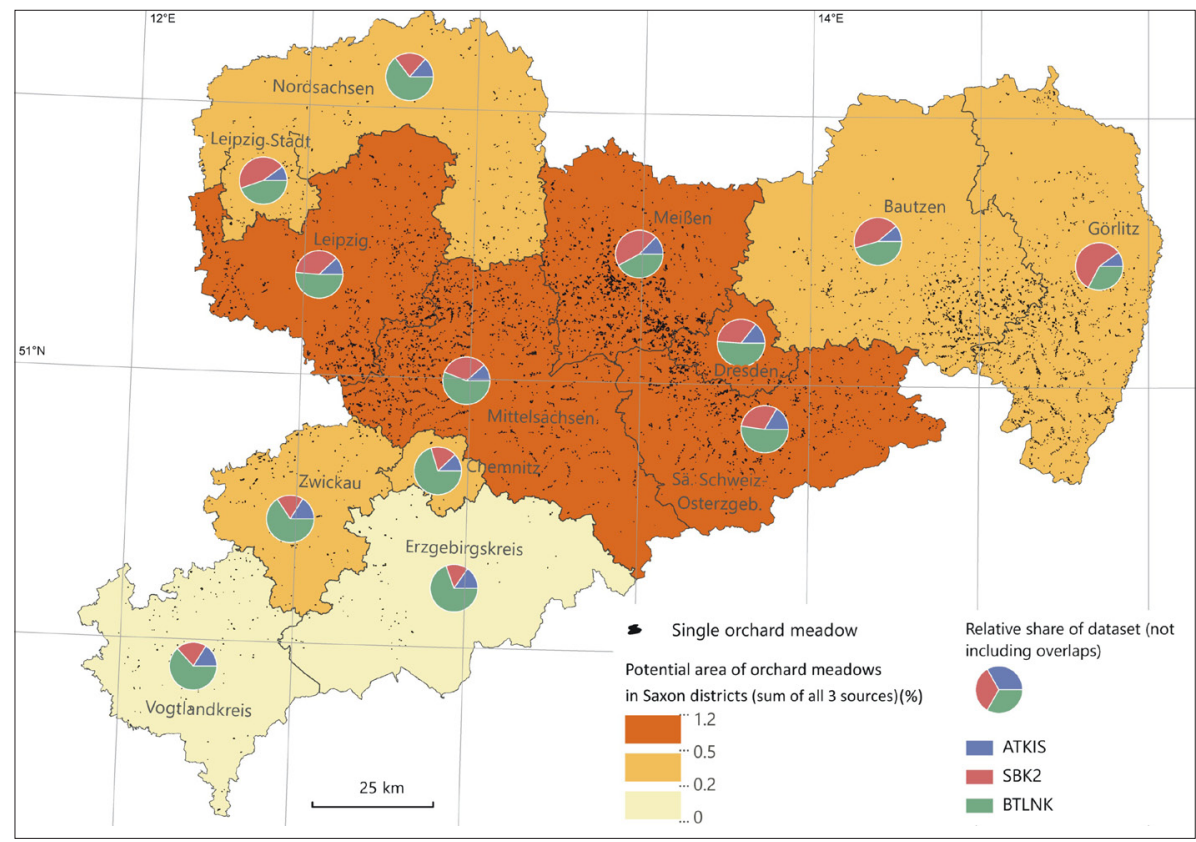

Fig. 3: Share of orchard meadows in Saxon administrative districts

Sources: BKG (2016), LfULG (2002), and LfULG (2005); authors' elaboration
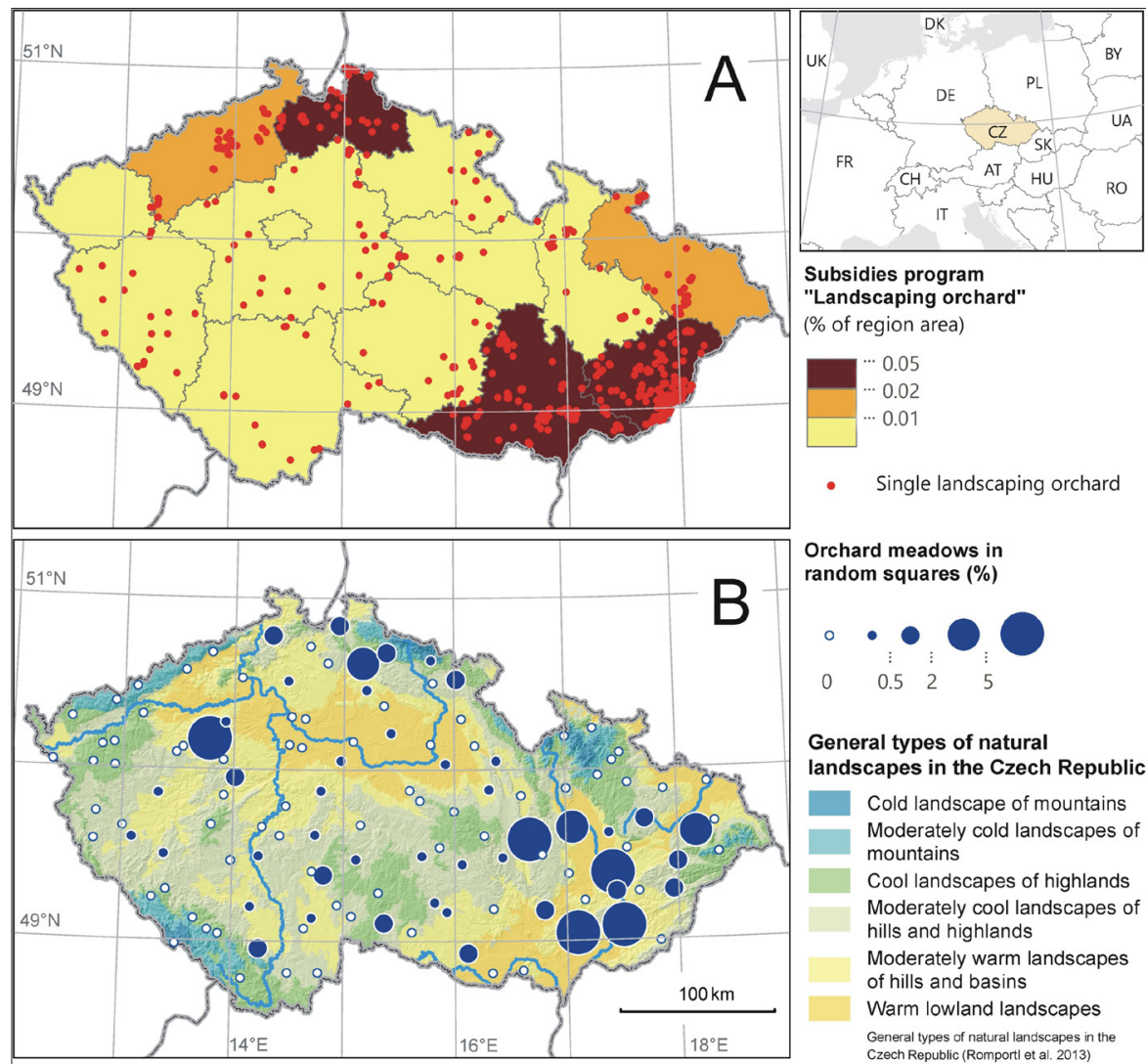

Fig. 4: The share of orchard meadows in the Czech Republic according to: A) LPIS (January, 2018); and B) authors' mapping based on aerial images (Č́ZZK, 2016, 2017) and mapy.cz street view application. Sources: Ministry of Agriculture of the Czech Republic (2018), Romportl et al. (2013), authors' survey; authors' elaboration 


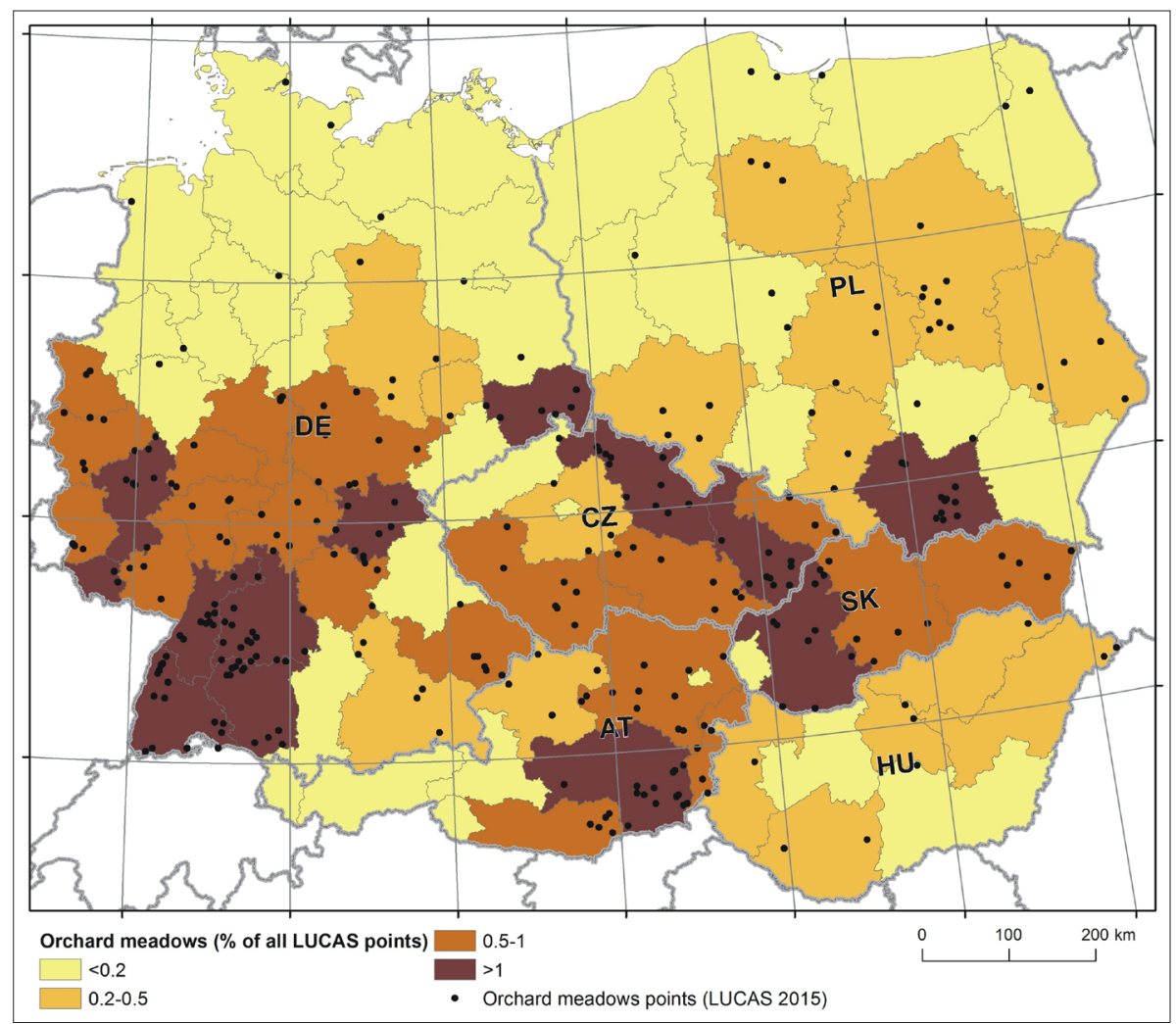

Fig. 5: Share of orchard meadows in Central European NUTS II units according to authors' verification of LUCAS points with fruit trees. Source: Eurostat (2015); authors' elaboration

Table 3 shows the share of points with interpreted orchard meadows in all mapping projects against the total point number of fruit trees. The highest values occur in Austria, Germany, and Slovakia, where orchard meadows make up about half of the fruit tree points. Lesser values are exhibited in the Czech Republic and very low shares are recorded in Poland and Hungary.

\section{Discussion}

Orchard meadows are a landscape feature typical for temperate Europe (Herzog, 1998). We used multiple geodata sources to estimate the area of orchard meadows and their spatial distribution in the Czech Republic and Saxony. Orchard meadows occupy a smaller share of the total area in Saxony than orchard meadows in the Czech Republic. This was confirmed by an additional source we used to crossreference the results, the LUCAS grid database. In Saxony it is the central part of the territory that has the highest density of orchard meadows. South-eastern and northern Czech Republic are also characterised by high concentrations of orchard meadow plots. We do not consider the mapping of 124 random squares sized $1 \mathrm{~km}^{2}$ each, however, to be a detailed orchard meadow distribution survey for Czech regions, rather we consider it to be an approximate localisation of large orchard meadow hot-spots.

Our study revises the previous area estimation of the total orchard meadow area in the Czech Republic. We estimate that the area is almost five times larger than the previous, often cited, estimate (Herzog, 1998). The present estimation suggests only a $15 \%$ decline since the mid- $19^{\text {th }}$ century in Bohemia, which accounts for two thirds of the current area of the Czech Republic (Krčmářová and Jeleček, 2017).

According to LUCAS, the share of orchard meadows in Saxony is higher than what other data (SBK2, BTLNK, ATKIS, random squares own mapping) would leave us to believe. It is apparent that this widely-used source (den Herder et al., 2017; Plieninger et al., 2015a) overestimates the area of orchard meadows. Since only accessible points located lower than 1,200 $\mathrm{m}$ above sea level are included in the LUCAS dataset, the reason for the overestimation could be that orchard meadows are usually located in

\begin{tabular}{lccc}
\hline Country & LC 1 = fruit trees & Orchard meadows & Share OM/Fruit trees (\%) \\
\hline Austria & 73 & 38 & 52.1 \\
Czech Republic & 121 & 41 & 33.9 \\
Germany & 273 & 144 & 52.7 \\
Hungary & 64 & 10 & 15.6 \\
Poland & 364 & 46 & 12.6 \\
Slovakia & 42 & 20 & 47.6 \\
\hline
\end{tabular}

Tab. 3: Share of orchard meadows on all plots with fruit trees in Central Europe according to LUCAS and own visual evaluation of photos (Note: this is not share of orchard meadows to total area [cf. Tab. 2])

Source: Eurostat (2015); authors' elaboration 
close proximity to villages and in rather hilly areas (Herzog, 1998). The area of land-uses with a similar spatial distribution (e.g. built-up area, gardens), is probably also overestimated, while land-uses typical for remote areas are underestimated in LUCAS. This important hypothesis should be tested in the future.

The LUCAS database, however, does give an overview and the possibility for comparison between several states and countries. When we compare different sources, especially in the cases of Saxon mapping projects, they agree only to a very small degree in the delimitation of orchard meadows. Such disagreement can be partly explained by the temporal extent of the mapping throughout the 20-year period (from 1996 to 2016). Another reason can be due to different mapping methods, as only SBK2 used on-site mapping, while ATKIS and BTLNK are based on remote sensing. Finally, orchard meadows are a transitional land use and the boundaries between them and the phenomena of gardens, intensive orchards, low-stemmed orchards, highdensity fruit tree stands or young fruit tree stands, are very unclear. It presents a good example of the often difficult effort involved in putting landscape features into a single category (Dahlberg, 2015) or even of classifying landscapes (Wolski, 2016).

Regarding the share of orchard meadows among all fruit tree land cover in the LUCAS database, we can conclude that the largest proportions of orchard meadows per total fruit tree growing area are in Austria and Germany. We can also assume a high self-supply of fruit in these countries corresponding to the fact that orchard meadows in the Swabian Alb are often managed by hobby farmers (Ohnesorge et al., 2015). On the other hand, Poland, an important apple producer, has a low share of orchard meadows for the large amount of fruit trees growing in the country.

Considering public support in the two case study areas, one can apply a complex measure for the specific land use (Czech Republic) or separate measures for planting new trees, sanitation of old trees, and management of grasslands (Saxony). In the case of the Czech Republic, only $2 \%$ of orchard meadow areas (derived from the estimation based on our mapping of the 124 random squares - an average of $0.55 \%$ ) receive subsidies designed for this land use in the 'landscaping orchard' program $\left(10.1 \mathrm{~km}^{2}\right.$ in the country). Paradoxically, in the cases of orchard meadows which were mapped by us, not a single plot was subsidised by any means. The Saxon approach is not based on spatial delimitation, thus we cannot precisely estimate the share of supported orchard meadow areas. We can approximately estimate from data of the number of projects and trees that about 100 plots received support for the planting of young trees and/or the sanitation of old trees. If we take the data from BTLNK, namely the mean orchard meadow size of 0.54 ha and the total area of the orchard meadows of $61.5 \mathrm{~km}^{2}$, we come to 54 supported hectares, which means that about $0.9 \%$ of orchard meadow areas are supported from the two programs. From the above-mentioned, it is apparent that the efficiency of public support towards orchard meadows is low in both Saxony and the Czech Republic.

Orchard meadows are land uses only partly covered by measures of CAP, even though they provide important ecosystem services. A similar case is the wood-pastures in Europe (Beaufoy, 2014; Jakobsson and Lindborg, 2015). This issue is discrepant with respect to the proclaimed intention of CAP to enhance the ecological functions of landscape. The presence of scattered trees on grassland (agroforestry) is considered to be an important climate change adaptation measure, yet as mentioned before, many orchard managers are hobby farmers (Ohnesorge et al., 2015), whose homesteads are not large enough to get public support. Since the orchard meadows are often managed by elderly people (Špulerová et al., 2015), there is a threat that traditional ecological knowledge connected with the care of fruit trees and fruit processing will fade away. Public awareness must be enhanced in both countries to attract younger people to adopt skills from people who still use them. If used, a more effective fruit production or new management practices such as cultivation of energy crops in the understorey, can lead to sustainability and the expansion of orchard meadows. (Schönhart et al., 2011; Plieninger et al., 2013).

One of the first steps to raise awareness of orchard meadows in the Czech Republic is to start using a specific term for the orchard meadows. Among landscape scientists, the term extenzivní sad ('extensive orchard') is used to describe orchard meadows as described above. If the same term were to be used by the general public, it could feel too professional and thus inappropriate. A better option could be luční sad ('meadowed orchard' or 'meadow orchard', where the meadow takes on a descriptive role). It seems important to use the word sad as a noun, rather than, for instance, the term sadová lúka ('orchard meadow', where sad is an adjective) as used in Slovakian research. The word luční (meadow-ish as a descriptor) specifies the type of orchard, sad being the only word used for an area of fruit production in an otherwise open landscape. The method of undergrowth management (whether pasture or mowing) could be deemed comparatively unimportant. Finally, the expression luční sad could be used as a label for products of orchard meadows, similar to the ways in which the word Streuobstwiese is used in relation to juices, jams, etc., in Germany.

\section{Conclusion}

Orchard meadows represent a landscape feature that is typical for temperate Europe: they provide a multitude of valuable ecosystem services. Based on the research presented in this study, both the Czech Republic and Saxony have high concentrations of orchard meadows in comparison with Central Europe in general. Orchard meadows cover more area in the Czech Republic than in Saxony, although they are protected by law only in Saxony, while the Czech language does not commonly use a distinctive term for orchard meadows let alone for them to be distinctly protected by the law. The information from recently available data sources differ too widely to set up a reliable monitoring program. In particular, data sources about orchard meadow coverage can differ. One estimation method differs from the other by almost $500 \%$ in Saxony (ATKIS - LUCAS) and by 7,200\% in the Czech Republic (LPIS-LUCAS). The main problem with extracting orchard meadows from thematic maps or statistical data sets lies in the fact that they are a transitional landscape type, without consistent recognition. The highest densities of orchard meadows are located in parts of the Czech Republic and Saxony where biodiversity hotspots are also present. The orchard meadow is a type of traditional agroforestry with not only high historic heritage and recreational values, but also an ecosystem with potentially high resilience towards climate change due to their species and genetic diversity. 
Some areas may even be called orchard meadow deserts, however - such as southwestern Czech Republic and the Ore Mountains - as these rather peripheral areas are regarded more for their touristic attractiveness, but they could benefit from a higher orchard meadow density.

The status of nature conservation differs essentially between the study areas. Whereas protection is directed to trees by the Czech legislation, in Saxony it is focused on the orchard meadow as a whole, which is not necessarily the case in the rest of Germany. Even though the latter approach of conservation seems to be more reasonable, regarding the share of orchard meadows on the whole area does not guarantee a higher quantity of this habitat type. Orchard meadows are subsidised from public budgets in both in Saxony and the Czech Republic, although with respect to the percentage of orchard meadows receiving such funds, the support cannot be really called efficient in either of them.

The high awareness of orchard meadows in Germany is generally highlighted by the well-known term (Streuobstwiese), which is frequently and successfully used, e.g. as a sales argument for fruits and juices produced in this sustainable manner. In Czech, a similar awareness could be raised by using the rather new expression luční sad, which feels ordinary and pleasant enough to get public appreciation. Since orchard meadows are often owned and maintained by elderly people, the threat of losing them in a long run must be countered by higher public attention and support. Policy agencies must find better solutions to protect these orchards in several areas, namely by improving the obvious small efficiencies of targetted subsidies and by enhancing overall data quality, so setting target values and their monitoring would be possible in future. We believe that the conservation and development of traditional knowledge connected with the orchard meadows can be raised by general interest, which is already partly being expressed by the activities of young and experienced farmers, NGOs, hobby clubs and public authorities.

\section{Acknowledgements}

We would like to thank the anonymous reviewers for their suggestions that helped to improve the manuscript. We also thank Sabine Witschas and Ulrike Schinke who helped us with design of the figures. The work reported on in this paper was supported by the Czech University of Life Sciences, Faculty of Environmental Sciences, project IGA FŽP, No. 20194230. The investigation was performed in the framework of the EU project BIDELIN (The value of ecosystem services, biodiversity and blue-green infrastructures in cities, exemplified by Dresden, Liberec and Děčin) (2017-2019), supported by the European Union, the Free State of Saxony (Germany) and the Czech Republic (Project No. 100282320)(IÖR, 2019).

\section{References:}

ANTROP, M. (2005): Why landscapes of the past are important for the future. Landsc Urban Plan, 70: 21-34. doi: 10.1016/j.landurbplan.2003.10.002.

BEAUFOY, G. (2014): Wood-pastures and the Common Agricultural Policy. Rhetoric and reality. In: Hartel T., Plieninger, T. [eds.]: European Wood-Pastures in Transition: A Social-Ecological Approach. Routledge, pp. 273-281.
COUNCIL OF THE EUROPEAN COMMUNITIES (1992): Directive 92/43/EEC of $21^{\text {st }}$ May 1992 on the conservation of natural habitats and of wild fauna and flora [online]. [cit. 22.01.2018]. Available at: https://eur-lex.europa.eu/legal-content/EN/TXT/ PDF/?uri=CELEX:31992L0043\&from $=$ EN

CZECH OFFICE FOR SURVEYING, MAPPING AND CADASTRE (2017): Orthophoto of the Czech Republic. [online]. [cit. 22.01.2018]. Available at: https:// geoportal.cuzk.cz/(S(ozvgtuliuqhe2buzqrmv3b0u))/ Default.aspx?mode $=$ TextMeta\&text = ortofoto info\&side $=$ ortofoto $\&$ menu $=23$

DAHLBERG, A. (2015): Categories are all around us: Towards more porous, flexible, and negotiable boundaries in conservation-production landscapes. Nor Geogr Tidsskr, 69:207-218. doi: 10.1080/00291951.2015.1060258.

DEMKOVÁ, K., LIPSKÝ, Z. (2015): Změny nelesní dřevinné vegetace v jihozápadní části Bílých Karpat v letech 1949-2011. Geografie-Sborník ČGS, 120(1): 64-83.

DEN HERDER, M., MORENO, G., ROSA, M., MOSQUERALOSADA, R. M., et al. (2017): Current extent and stratification of agroforestry in the European Union. Agriculture, Ecosystems \& Environment, 241: 121-132. doi: 10.1016/j.agee.2017.03.005.

EUROSTAT (2015): LUCAS primary data 2015 [online]. [cit. 22.01.2018]. Available at: https://ec.europa.eu/eurostat/ web/lucas/data/primary-data/2015

EWERT, J. (2019): Erhalt und Aufwertung von Streuobstwiesen in urbanen Räumen am Beispiel Dresden (Masterarbeit). Dresden, Technische Universität Dresden.

FISHER, M. (2007): Streuobst - Betreiberkonzepte und sortenempfehlung. Erwerbs-Obstbau, 49: 141-147. doi: 10.1007/s10341-007-0049-5.

GÖTTLICHER,H.-P.(1999): Sächsisches Naturschutzgesetz : (SächsNatSchG); Kommentar. Kommunal- und Schulverl, Wiesbaden.

HANUŠIN, J., LACIKA, J. (2018): Vybrané environmentálne súvislosti zmien historickej lazníckej krajiny (na príklade obce Hrušov okres Vel'ký Krtîš). Geografický časopis, 70: $57-77$.

HERZOG, F. (1998): Streuobst: A traditional agroforestry system as a model for agroforestry development in temperate Europe. Agroforestry Systems, 42(1): 61-80. doi: 10.1023/A:1006152127824.

HORAK, J. (2014): Fragmented habitats of traditional fruit orchards are important for dead wood-dependent beetles associated with open canopy deciduous woodlands. Naturwissenschaften, 101: 499-504. doi: 10.1007/ s00114-014-1179-x.

HORAK, J., PELTANOVA, A., PODAVKOVA, A., SAFAROVA, L., BOGUSCH, P., ROMPORTL, D., ZASADIL, P. (2013): Biodiversity responses to land use in traditional fruit orchards of a rural agricultural landscape. AgricULTURE, ecosystems \& environment, 178: 71-77. doi: 10.1016/j.agee.2013.06.020.

JAKOBSSON, S., LINDBORG, R. (2015): Governing nature by numbers - EU subsidy regulations do not capture the unique values of woody pastures. 
Biological Conservation, 191:1-9. doi: 10.1016/j. biocon.2015.06.007.

KAJTOCH, Ł. (2017): The importance of traditional orchards for breeding birds: The preliminary study on Central European example. Acta Oecologica, 78: 53-60. doi: 10.1016/j.actao.2016.12.010.

KRČMÁŘOVÁ, J., JELEČEK, L. (2017): Czech traditional agroforestry: historic accounts and current status. Agroforestry Systems, 91(6): 1087-1100. doi: 10.1007/ s10457-016-9985-0.

LfULG (2002): Karten und Geodaten der Selektiven Biotopkartierung im Offenland in Sachsen [online]. [cit. 22.01.2018]. Available at: https://www.umwelt. sachsen.de/umwelt/natur/30735.htm\#article30751

LfULG (2005): Biotoptypen- und Landnutzungskartierung (BTLNK). Sächsisches Landesamt für Umwelt, Landwirtschaft und Geologie [online]. [cit. 22.01.2018]. Available at: https://www.umwelt.sachsen.de/umwelt/ natur/25140.htm

MANNSFELD, K., SYRBE, R.-U. (2008): Naturräume in Sachsen. Deutsche Akademie für Landeskunde, Leipzig.

MILTON， S. J.， DEAN， W. R. J.， KLOTZ， S. (1997): Thicket Formation In Abandoned Fruit Orchards: Processes and Implications For the Conservation Of Semi Dry Grasslands In Central Germany. Biodiversity and Conservation, 6(2): 275-290. doi: 10.1023/a:1018300321411.

MINISTRY OF AGRICULTURE OF THE CZECH REPUBLIC (2016): Metodika $\mathrm{k}$ provádění nařízení vlády č. 76/2015 Sb., o podmínkách provádění opatření ekologické zemědělství, ve znění pozdějších předpisů pro rok 2016, Praha, Ministerstvo zemědělství.

MINISTRY OF AGRICULTURE OF THE CZECH REPUBLIC (2018): Landscaping orchards, shapefile. $22^{\text {nd }}$ January 2018.

NERLICH, K., GRAEFF-HÖNNINGER, S., CLAUPEIN, W. (2013): Agroforestry in Europe: A review of the disappearance of traditional systems and development of modern agroforestry practices, with emphasis on experiences in Germany (Agroforestry Systems, 87(2): 475-492, doi: 10.1007/s10457-013-9618-9.

OHNESORGE, B., BIELING, C., SCHLEYER, C., PLIENINGER, T. (2015): The Example of Orchard Meadows in the Swabian Alb Biosphere Reserve. In: Grunewald, K., Bastian, O. [eds.]: Ecosystem Services - Concept, Methods and Case Studies (pp. XII, 312). Springer-Verlag Berlin Heidelberg.

PLIENINGER, T. (2012): Monitoring directions and rates of change in trees outside forests through multitemporal analysis of map sequences. Applied Geography, 32(2): 566-576. doi: 10.1016/j.apgeog.2011.06.015.

PLIENINGER, T., BIELING, C., OHNESORGE, B. et al. (2013): Exploring Futures of Ecosystem Services in Cultural Landscapes through Participatory Scenario Development in the Swabian Alb, Germany. Ecology and Society, 18(3): art39. doi: 10.5751/ES-05802180339.

PLIENINGER, T., HARTEL, T., MARTÍN-LÓPEZ, B., BEAUFOY, G., BERGMEIER, EL, |KIRBY, K., MONTERO M. J., MORENO, G., OTEROS-ROZAS, E.
UYTVANCK, V. (2015a): Wood-pastures of Europe: Geographic coverage, social-ecological values, conservation management, and policy implications. Biological Conservation, 190: 70-79. doi: 10.1016/j. biocon.2015.05.014.

PLIENINGER, T., LEVERS, C., MANTEL, M., COSTA, A., SCHAICH, H., KUEMMERLE, T. (2015b): Patterns and drivers of scattered tree loss in agricultural landscapes: orchard meadows in Germany (1968-2009). PLoS One, 10(5): e0126178. doi: 10.1371/journal.pone.0126178.

ROST, K. (2011): Ergebnisse der Streuobstkartierung im Biosphärenreservat Karstlandschaft Südharz. Naturschutz im L Sachsen-Anhalt, 48: 135-140.

SCHÖNHART, M., SCHAUPPENLEHNER, T., SCHMID, E., MUHAR, A. (2011): Analysing the maintenance and establishment of orchard meadows at farm and landscape levels applying a spatially explicit integrated modelling approach. Journal of Environmental Planning and Management, 54(1): 115143. doi: 10.1080/09640568.2010.502763.

ŠPULEROVÁ, J., PISCOVÁ, V., GERHÁTOVÁ, K., BAČA, A., KALIVODA, H., KANKA, R. (2015): Orchards as traces of traditional agricultural landscape in Slovakia. Agriculture, Ecosystems \& Environment, 199: 67-76. doi: 10.1016/j.agee.2014.08.021.

STAATSBETRIEB GEOBASISINFORMATION UND VERMESSUNG SACHSEN (2016): ATKIS-OK BasisDLM Sachsen.

STEFFAN-DEWENTER I., LESCHKE, K. (2003): Effects of habitat management on vegetation and above-ground nesting bees and wasps of orchard meadows in Central Europe. Biodiversity \& Conservaton, 12(9): 1953-1968. doi: 10.1023/A:1024199513365.

THIEL, A., SCHLEYER, C., PLIENINGER, T. (2012): Wolves are Mobile, While Fruit Trees are not! How Characteristics of Resources and Supranational Regulatory Frameworks Shape the Provision of Biodiversity and Ecosystem Services in Germany. Environmental Policy and Governance, 22(3): 189-204. doi: 10.1002/eet.1578.

THIEM, K., BASTIAN, O. (2014): Historische Kulturlandschaftselemente Sachsens. Landesamt für Umwelt, Landwirtschaf und Geologie (Freistaat Sachsen).

TOJNKO, S., ROZMAN, Č., UNUK, T., PAŽEK, K., PAMIČ, S. (2011): A Qualitative Multi-Attribute Model for The Multifunctional Assessment of "Streuobst Stands" in NE Slovenia. Erwerbs-Obstbau, 53(4): 157-166. doi: 10.1007/s10341-011-0149-0.

TÓTH, A., TIMPE, A. (2017): Exploring urban agriculture as a component of multifunctional green infrastructure: Application of figure-ground plans as a spatial analysis tool. Moravian Geographical Reports, 25(3): 208-218. doi: 10.1515/mgr-2017-0018.

WOLSKI, J. (2016): The landscape of abandoned villages in the western bieszczady: The problem of definition and classification. Geographia Polonica, 89(3): 371-387. doi: 10.7163/GPol.0064.

ŽARNOVIČAN, H. (2012): Manažment sadových lúk myjavsko-bielokarpatských kopaníc $\mathrm{v}$ minulosti a v súčasnosti. Životné prostredie, 46(5): 271-275. 
ŽARNOVIČAN, H., KOLLÁR, J., ŠKODOVÁ, I. (2017):

Grassland communities of traditional orchards in the Western Carpathians (Slovakia). Acta Societatis Botanicorum Poloniae, 86(2): 1-16. doi: 10.5586/ asbp.3552.

ILLICH-OLLECK, A., BAUSCHMANN, G. (1991): Die Aktion "Rettet die Obstwiesen" als Möglichkeit zur Erhaltung gefährdeter Tier- und Pflanzenarten. Artenschutzreport, 1: 33-35.
ZOPK (2017): Zákon č. 123/2017 Sb. Zákon, kterým se mění zákon č. 114/1992 Sb. o ochraně přírody a krajiny, ve znění pozdějších předpisů

\section{Please cite this article as:}

FOREJT, M., SYRBE, R. U. (2019): The current status of orchard meadows in Central Europe: Multi-source area estimation in Saxony (Germany) and the Czech Republic. Moravian Geographical Reports, 27(4): 217-228. Doi: 10.2478/mgr-2019-0017. 